\title{
"Improved" Sand Dams for Wildlife Habitat Management
}

\author{
VERNON C. BLEICH AND RICHARD A. WEAVER
}

\section{Abstract}

Suggestions for improving the efficiency, dependability, and simplicity of the sand dams described by Sivils and Brock (1981) are presented. Recommendations which may result in decreased installation and maintenance costs are included.

Sivils and Brock (1981) recently presented suggestions for the development of sand dams to increase water availability in arid regions. While the idea is not new (see Halloran and Deming 1956, 1958), its presentation is timely because earlier designs failed to incorporate subterranean, soil-free reservoirs. The design of Sivils and Brock, however, is not without potential flaws and is unnecessarily complicated. We, therefore, offer suggestions for improving the efficiency and dependability of such devices, while simultaneously increasing their simplicity.

The most vulnerable part of the system is the float valve. Float valve failures have been a major problem in guzzlers installed for mountain sheep in California (Bleich et al. 1979). They are subject to jamming by foreign objects, including sand particles, organic material, or small rocks, which may lodge in the valve seat, causing the valve to stay open and drain the stored water. To minimize this possibility a 30-cm (1-foot) length of capped $15-\mathrm{cm}$ diameter well screen (Johnson Screen) should be connected via a bell reducer to a $50-\mathrm{mm}$ (2-inch) outlet pipe on the upstream side of the dam. Such a screen will prevent particles larger than $0.75 \mathrm{~mm}$ from entering the drinker line, thereby decreasing the chance of a float valve failure. Replacing the pipe passing through the dam, should it bc broken by falling rocks (Bleich et al. 1979), is difficult. We recommend that the outlet pipe be galvanized material; if desired, the drinker line, which is more easily replaced, may be plastic.

It is unnecessary to plumb the collecting culverts into a common outlet, as suggested by Sivils and Brock, because stored water will naturally seek the lowest point behind the dam, flowing through rocks, sand, the Johnson Screen, the outlet pipe, and into the drinker line. Of course, the outlet must be located at the lowest possible point on the dam. The time and money saved by not plumbing the culverts to a common point may be substantial.

If a relatively high dam is to be constructed, the culverts may be "layered" to increase storage capacity. Again, the water level in the culverts will decrease as water is used at the drinker. In order to minimize potential damage from initial heavy food flows, layered culverts should be bolted together, and the bottom layer should be attached to the rock substrate with rebar or other suitable material. Once the dam has naturally backfilled with sand and gravel, this

The authors are associate wildlife biologist, California Department of Fish and Game, P.O. Box 1741, Hemet 92343; and associate wildlife biologist. California Department of Fish and Game, 1416 Ninth Street, Sacramento 95814

This report is a contribution from California Federal Aid in Wildlife Restoration Projects W-26-D (Wildlife Habitat Development) and W-51-R (Big Game Investigations).

Manuscript received February 23, 1982 problem will diminish. It will be necessary to drill into the rock to anchor the collection system.

It is not necessary to drill holes throughout the top third of the culverts as suggested by Sivils and Brock, because the ends of the culverts are not tightly sealed. A few large rocks, or heavy wire screen placed over the ends of the culverts will allow the culverts to fill and drain adequately, and the savings in man hours of drilling alone may be substantial.

The design and construction of the dam may be the most important aspect of the entire system. Because of the low evaporative capacity of a thick layer of sand (National Academy of Sciences 1974); seepage at the concrete/bedrock interface may be of substantial importance in determining how long a given amount of stored water will last. For the most efficient dams, we suggest following the guidelines outlined by Gray (1974).

Sand dams have great potential for improving wildlife habitat in arid regions. Several species, including mountain sheep, are thought to have declined substantially as a result of recent drought conditions (Weaver 1973). Although traditional spring developments (Weaver et al. 1958), guzzler installations (Bleich et al. 1979), and even technologically advanced methods (Bleich et al. in press) are available, we feel there is good potential for the application of "improved" sand dams to the management of wild life habitat. We emphasize, however, that the sand dams must be dependable, efficient, and economical to construct. The suggestions presented here will help others to achieve those objectives.

\section{Literature Cited}

Bleich, V.C., L.J. Coombes, and J.H. Davis. 1979. Big game guzzler evaluations: progress report I. Calif. Dep. Fish and Game, Long Beach.

Bleich, V.C., L.J. Coombes, and J.H. Davis. In press. Horizontal wells as a wildlife habitat improvement technique. Wildlife Soc. Bull.

Gray, R.S. 1974. Lasting waters for bighorn. Desert Bighorn Counc. Trans. 1974:25-27.

Halloran, A.F., and O.V. Deming. 1956. Water development for desert bighorn sheep. U.S. Fish and Wildl. Serv., Wildl. Manage. Ser. Leafl. 14

Halloran, A.F., and O.V. Deming. 1958. Water development for desert bighorn sheep. J. Wildl. Manage. 22:1-9.

National Academy of Sciences. 1974. More water for arid lands. A report to the Advisory Committee on Technology Innovation, Board on Science and Technology for International Development Commission on International Relations. Washington, D.C.

Sivils, B.E., and J.H. Brock. 1981. Sand dams as a feasible water development for arid regions. J. Range Manage. 34:238-239.

Weaver, R.A. 1973. California's bighorn management plan. Desert Bighorn Counc. Trans. 1973:22-42.

Weaver, R.A., F. Vernoy, and B. Craig. 1959. Game water development on the desert. Calif. Fish and Game 45:333-342. 